\title{
Interfaith Marriage and The Legal Consequence of Its Validity
}

\author{
Alia Harumdani Widjaja ${ }^{1}$ \\ \{jengsolo@gmail.com\} \\ Center for Research and Case Studies and Library Management, Constitutional Court, Jakarta, Indonesia
}

\begin{abstract}
The Interfaith marriage often leaves validity of marriage's problem. The concept of interfaith marriage often clash with the concept of human rights which is strengthened by the Constitutional Court Decision Number 68/PUU-XII/2014 in the relation to the judicial review of Law Number 1 of 1974 concerning Marriage which rejects the issue of interfaith marriage. After that, the State consider to curb the freedom of individual human rights to choose a mate and find happiness with their spouses from different religions. This paper will discuss how far the State has a role to solve the validity of interfaith marriage. Through normative legal research method, this paper offers the need for affirmation as well as restrictions from the State as outlined in the policy so that, the suitability of the purpose of marriage is not only private or civil but also religious in nature (involving Allah SWT or Almighty God).
\end{abstract}

Keywords : Interfaith Marriage, Validity.

\section{Introduction}

In Islam, marriage is called as mitsaqan ghaliza or "solid agreement" which is stated in the Qur'an AnNisa verse : 21 . This bond is named by Allah which involves an agreement between the spouses. This means that marriage is not a treaty that can be played with because it involves a relationship with Allah SWT. The dilemmatic condition seems to be the right condition to describe the situation or condition of marital arrangements in Indonesia today. Law Number 1 of 1974 concerning Marriage (hereinafter referred to as Marriage Law) does not explicitly regulate the prohibition of interfaith marriage, but in Article 2 paragraph (1), it only states that marriage is legal if carried out according to their religion and belief.

\section{Method}

The research method in this article uses the study of a normative legal research through study and analyze the literature materials which not only identifies written laws as a norm, but also unwritten laws. This research uses primary and secondary data or material which obtained from literature study and through other knowledge media.

\section{Result and Discussion}

\section{a. Legal Consequence of The Validity Of Interfaith Marriage}

As known before, the product of legal policy is the authority of legislators both at the central and regional levels. An interesting idea put forward from an article in a journal that making a legal policies with a level legal for example, such as an act, needs to involve what is called the Religious Council in Indonesia which consists of representatives of all religious organizations throughout Indonesia. Religious Councils have no role by any means in the formation of legal policies related to inter-faith marriage since the Marriage Law had been created before the Religious Councils established. Instead of limiting the cohabitation of inter-faith couples, albeit religious leaders favor or disfavor inter-faith marriage, the practice is still widely flourished and rapidly increased. [1] The implication that arise from the absence of a clear law is that many scholars who are members of Islamic Organizations and other religious leaders, socialize the fatwa about interfaith marriage to the public with the aim to make people understand about the legal position of different religious marriage. In Islam, for example, KH. Siddiq Amien views that interfaith marriage will be burdened with several other sharia laws, for example it will greatly affect the children's education, there will be many tensions about religion that will be adopted by children born between their 
parents, then there will be no way or closed about the way to inherit due to religious differences (ikhtilafuddin). [2]

Such is not the case in many Islamic countries, The broad body of Islamic Law, known as Shari'a, draws no distinction between sacred and secular. In addition to setting forth God's laws for prayer, fasting, and professing faith, Shari'a also deals with politics, economics, banking, trade, family law, evidence and procedure, sexuality, dress, hygiene, dietary laws, and criminal laws. [3] So, thus, in fact there is no more bargaining or even an expanded interpretation especially regarding interfaith marriage where one of the spouses is a Muslim itself. However, sometimes in the name of modernity, the person who did the interfaith marriage (especially one of whom are Muslims) continue to do so, because their logical frame of thingking views that marriage matters, whom known include one of secular affairs, need to be distinguished from divinity matters. In fact, true marriage is an agreement of sacred ties between men and women before Allah SWT.

Additionally, Shari'a represents a "standard of uniformity" which protects against the inconsistent and contradictory systems that would inevitably result if people were left to legislate according to their local circumstances.

The problem which arises is how about the legal consequence of interfaith marriage validity that are private to its citizen?

In fact, the nature of private law or family law in Indonesia is cannot be rigid like public law such as criminal law. It is actually inconceivable if the State regulates very rigidly about marital law until there is a criminal sanctions'article in the law, except for special cases such as domestic violence which is very important to be regulated separately because to protect the victim (it can be the husband or wife) and there is an element of criminality for the perpretator.

The definition of marriage in Article 1 of the Marriage Law, put the element of religiousity. Therefore, it's no longer secular, but in practice it will be different if the interfaith marriage happens. A dilemma arises, because on the one hand we have to respect humanity or human rights, on the other hand, there are deviations from the provisions of the Marriage Law which imply a legal marriage based on religion (the condition of marriage in same religion).. Meanwhile, Article 2 paragraph (1) of the Marriage Law is a differential unification and complements the interfaith marriage laws about Islam with the Islamic law and Islamic Compilation of Laws, Christianity with HOCI and Europeans with its Civil Code. Differential means to refer to the respective religious law, including beliefs. [4]

Actually, the Constitutional Court Decision Number 68/PUU-XII/2014 in the relation to the judicial review of Marriage Law, has provided a solution to the problem of interfaith marriage based on the statements of the parties including experts and also representatives of all religious organizations or religious council in Indonesia which on average do not allow interfaith marriage. But, of course, this solution is only from one element of government institution, namely the court institution. Even though it does not need to be responded by the legislators, because no article of an act has been annulmented, it is only necessary to note to all legal stakeholders that, even though religion and the state are prohibited, in practice, interfaith marriage still happens and the implication is that there are some difficulties in matters of administrative registration which can then affect the validity of his marriage. Because, beside article 2 paragraph (1) which regulates marriage is legitimate if it has been performed according to the laws of the respective religious beliefs of the party concerned, there is a cumulative or one "breath" with article 2 paragraph (2) of the Marriage Law which states that each-Every marriage is recorded or registrated according to applicable laws and regulations. This means, if the marriage is not legitimate or valid according to their religion, then the marriage cannot be recorded or registered administratively. As if seen from this, the proof of administrative marriage is the most important evidence to state that marriage is legal or legitimate.

In fact, the state has indirectly "punished" the couple who did the interfaith marriage through "the difficulties in the administration of registration". However, the problem is, this marriage is still continue with the reality of continuity of survival together between the couple who did interfaith marriage. This is show to us about the characterizes of the existence of private law, which has relation with familial, will become slack about the its existence.

For people who are married with different religions, which one of the couple are moslem, strengthen their interfaith marriage with the following opinion: [5]

1. That the plurality of religions is the sunnatulah that can not be avoided, God calls the celestial religions and they bring the teachings of good deeds as people who will be with His heaven in heaven later. Even God also explicitly stated that differences in sex gender and ethnicity can be as a sign that 
one knows each other and marriage between different religions can be used as a space, in which between believer can get to know each other more closely.

2. That the purpose of the marriage is to build love (al-mawaddah) and rope of the affection of love (alrahmah). In the middle of the susceptive interreligious relations nowadays, interfaith marriage can actually be used as a vehicle to build tolerance and understanding between each religion. Starting from the bond of love and affection, knitted with harmony and peace.

3. The spirit which brought by Islam is liberation, not shackles and stages carried out by the Qur'an since the prohibition of marriage with polytheists or worshipper other than God, then paving the way for marriage with Ahl-Alkitab (Jewish and Christian) is an evolutionary stage of liberation and in due course, we must see other religions not as a second class and not ahl-dzimmah (Independent nonMoslem people who live in a country that runs the Islamic Shari'a and receives protection and security), not to supress them, but treat them as citizens.

Truly, a thought that involves a relationship with God or Allah SWT cannot be based solely on human tastes or desires, without regard to the Islamic Shari'a or God's laws. This should also apply to the rationale for legal policy products.

To be honest, the issue regarding the validity of interfaith marriage also exacerbates the fact that there are two different products of court law regarding these religious differences. There is a contradiction between the Constitutional Court's Decision and the Supreme Court's Decision namely MA Decision Number $1400 \mathrm{~K} / \mathrm{Pdt} / 1986$ which allows the Civil Registry Office to carry out actual interfaith marriage. The existence of these two court legal products should be a note for legislators to contribute the way out if there is a practice of interfaith marriage.

In fact, in the end, the existence of these two legal avenues adds to the confusion of the legal consequence the validity of interfaith marriage. On the one hand, if it refers to the Supreme Court's Decision, interfaith marriage may become legal and valid according to the laws of the respective religious beliefs of the party concerned, while if they refer to the Constitutional Court Decision, interfaith marriage can become null and void according to the laws of the respective religious beliefs.

Here, we can see that, in terms of the harmonization of law, the reality that occurs is that the products of the judicial law are not yet seen as supporting one another.

In here, the writer as a researcher never mean to judge the couple who did the interfaith marriage, especially if one of them has the same religion with the writer, a Moslem. However, one thing that need to be considered are physical and spiritual peace, convenience of the relationship with God or Allah SWT and the benefit also include the goals and essential elements of a marriage. Moreover, for among the Islamic religion itself, marriage is also a form of worship and refer to realize a half of the religion which means there is an element of involvement of Allah SWT in marital relations.

\section{b. Legal Policy for Legal Solution Regarding The Legal Consequence of Interfaith Marriage : Different Treatment For Interfaith Marriage}

What about the interfaith marriage that have already taken place and how about the legal consequence of its validity? There is no firmness from the State which states that it is prohibited or that it must be canceled and then the couple who did the interfaith marriage are subject to sanctions. Perhaps, It is because of the nature of this private law, which seems to make the State still in the territory that is very careful to decide, eventhough, one of the representation of the State through a constitutional court, has implied indirectly that interfaith marriage is illegal according to applicable law.

Apart from the polemic of interfaith marriage, what needs to be considered by legislators and the officials of executive authorities is to make a little assertiveness of the provisions governing legal marriage such as, whether to make slacker for interfaith marriage, or still affirmed based on their respective religions and beliefs without opening the opportunity for further interpretation of the provisions of the article. This is because we cannot rule out the fact that even if it is not permitted, interfaith marriage still exists.

Even, for example, the State still wants to loosen the possibility of interfaith marriage practices, the State needs to regulate the different treatment of those interfaith marriage both in terms of its (specific) legal policy products to the implications and consequence attached to them including the administrative registration issues.

Not intending to punish the couple who did the interfaith marriage, this paper has the aim to rather looking for solutions in the middle of chaotic policies of interfaith marriage that is not clear so that it can have an impact on the illegitimacy of their marriage. 


\section{Conclusion}

Basically Interfaith Marriage is not regulated explicitly in the Marriage Law. However, on the basis of human rights, the practice of interfaith marriage is now widely practiced. The problem is that the existence of interfaith marriage in Indonesia has implications for the difficulties of administrative registration which become a legal requirement for the legitimate of marriage in Indonesia. The Constitutional Court Decision Number 68 / PUU-XII / 2014 in the relation to the judicial review of Law Number 1 of 1974 on Marriage actually indirectly affirms the refusal of interfaith marriage. Actually, the state indirectly provides some kind of compensation to the couple who did the interfaith marriage in the form of the difficulty of being registered administratively. The difficulty of being registered administratively is the legal consequence of the interfaith marriage. Basically family law because its so privately, its nature can not be rigid as a criminal law that can easily provide criminal sanctions to people who are considered to have violated the provisions of criminal law. Regardless of the polemic of interfaith marriage, the thing that lawmakers or legislators and the officials of executive authorities need to pay attention as a legal policy is to make a little firmness about the provisions governing legal marriage, or if the state needs to provide separate legal policies or specifically (different) for the couple who did interfaith marriage, then the State can provide it. At least, so that, their validity is recognized for those who have already engaged in interfaith marriage.

\section{References}

[1] Rosdiana, Ummu Hasanah Yusuf Saumin \& Masayu Mashita Maisarah : Legitimacy On InterfaithMarriage : An Analysis of The Role of Religious Councils on The Legal Policy in Indonesia. AHKAM, Vol. 19 (1), pp. 94 (2019).

[2] Yusuf Badri : Nikah Beda Agama, pp.127-143. Persis Press, Bandung, Indonesia (2009).

[3] Alex B. Leeman, Interfaith Marriage in Islam: An Examination of the Legal Theory Behind the Traditional and Reformist Positions. Indiana Law Journal, Vol. 84 (73), pp. 745 - 746 (2009).

[4] Interview with Hartini, Islamic Law Specialists Lecture from the University of Gajah Mada Yogyakarta, in the Call For Paper Activity Report and Law and Justice Seminar at Yogyakarta Muhammadiyah University and the Research Data Retrieval Report about "Decision of the Constitutional Court Related to Marriage and Political Consistency of Marriage Law in Indonesia" on March 9 - March 12, 2020.

[5] Nurcholis Madjid et.al, Fiqih Lintas Agama : Membangun Masyarakat Inklusif-Pluralis, Jakarta, Paramadina, 2004 dalam Ali Mustafa Yaqub, Nikah Beda Agama dalam Al-Qur'an dan Hadis, Jakarta : Pustaka Firdaus, 2007, Page17 -18. 